\title{
Effect of Long-Term Hypodynamy on Alkaline Phosphatase Activity of Small Intestine in Japanese Quail Chicks
}

\author{
L. LENHARDT, V. CIGÁNKOVÁ, V. ALMÁŠIOVÁ, K. HOLOVSKÁ Jr., P. ŠKROBÁNEK ${ }^{1}$, \\ Š. MOZEŠ², M. ZIBRÍN \\ University of Veterinary Medicine, Košice, Slovak Republic \\ ${ }^{1}$ Institute of Animal Biochemistry and Genetics, Slovak Academy of Sciences, Ivanka pri Dunaji, \\ Slovak Republic \\ ${ }^{2}$ Institute of Animal Physiology, Slovak Academy of Sciences, Košice, Slovak Republic \\ Received February 16, 2007 \\ Accepted June 5, 2007
}

\begin{abstract}
Lenhardt L., V. Cigánková, V. Almášiová, K. Holovská Jr., P. Škrobánek, Š. Mozě̌, M. Zibrín: Effect of Long-Term Hypodynamy on Alkaline Phosphatase Activity of Small Intestine in Japanese Quail Chicks. Acta Vet. Brno 2007, 76: 333-338.

The functional development of the small intestine was investigated in Japanese quail chicks subjected to simulated microgravity (hypodynamy) on the second day after hatching and reared under these conditions to 63 days of age. On days 5, 7, 14, 21, 28, 35, 42, 56 and 63 the activity of brush-border-bound alkaline phosphatase (AP) in the duodenum and jejunum were determined in experimental animals as well as in control quail chicks housed in a floor box during these periods. As compared with control quails the experimental animals displayed a significantly increased enzyme activity until day 42 in the duodenum and day 35 in the jejunum $(P<0.001)$ whereas in older quails no significant enzymatic differences between these groups was found. However, a decrease in food consumption due to a partial physical constraint cannot be excluded. Moreover, the results suggested that the activity of AP in the control birds did not change substantially during all the periods examined. In contrast, in older hypodynamy quail the AP activity significantly decreased in the duodenum on days 56 and 63 and in the jejunum on days 42,56 and 63, respectively. These results indicate that a) the enhanced intestinal function in early periods of life may reflect the higher sensitivity of small intestine to simulated weightlessness, b) the decrease of the AP activity in older animals to the level of controls might be considered as a part of intestinal mechanisms involved in adaptation of quail chicks to long-term hypodynamy, c) differnt activity of AP in the small intestine of Japanese quail may not have resulted only from hypodynamy but also due to decreased food intake.
\end{abstract}

Simulated microgravity, enzymatic activity, duodenum and jejunum, brush-border, growth, Japanese quail

Hypodynamy is a method that simulates weightlessness on Earth under laboratory conditions. In general, long-term experimental hypodynamy has adverse effect on Japanese quails and acts as a stress factor leading to hypertrophy of the adrenal glands (Cigánková et al. 2005) and to an increase in plasma concentration of catecholamines (Juráni et al. 1983, 1988). Moreover, it has also been demonstrated that in Japanese quail chicks simulated microgravity from day 2 after hatching to day 56 of age caused marked abnormalities in their somatic development and feeding behaviour. In comparison with age-matched controls the experimental chicks had lower body weight and displayed impaired leg bone growth as well as decreased food consumption (Škrobánek et al. 2004, 2005). It is clear that low energy intake might be considered as a general signal for control mechanisms regulating growth and development, the precise mechanisms responsible for metabolic adaptation to simulated weightlessness are poorly understood.

The food availability and its digestion may also be a significant factor involved in developmental disturbances of post-hatch birds since the reduced body weight and growth rate is a common finding of nutrient restriction (Rajman et al. 2006; Van Der

Address for correspondence:

Associated Prof. Ludovít Lenhardt, $\mathrm{PhD}$

University of Veterinary Medicine

Komenského 73, 04181 Košice

Slovak Republic

E-mail: lenhardt@uvm.sk

http://www.vfu.cz/acta-vet/actavet.htm 
Ziel and Visser 2001). In agreement with this the intensive somatic growth observed during early growth stages coincides with rapid morphological and functional changes in the digestive tract of birds (Baranyiová 1972; Uni et al. 1995, 1999) whereas delayed access to food or its decreased utilization inhibits development of the intestinal mucosa and slow down the body weight gain for several days after hatching (Uni et al. 1998; Shapiro et al. 1998). One of the enzymes of the small intestine is alkaline phosphatase (AP) present mainly in the brush-border of absorption cells of the intestinal villus where it participates in the active uptake and transport of nutrients. From developmental aspect AP activity is considered to be a marker of cellular differentiation/maturation and this enzyme is expressed during migration of intestinal enterocytes from crypt to villus tip (Weiser 1973). In previous studies we observed that the chicks were not able to feed normally during the first days after hatching due to short-term space microgravity. This leads to a significant increase in the AP activity in the duodenal and jejunal enterocytes of Japanese quails on days 4-5 of age (Lenhardt et al. 2001). These results indicate an altered functional development of its digestive tract, however, the response of the small intestine to hypodynamy in older chicks is poorly understood. It is therefore conceivable that investigation of AP activity throughout the long-term experiment may help us to understand the intestinal background of the somatic and feeding adaptations to weightlessneess observed during the later periods of life. Accordingly, the activity of brush-border-bound AP was therefore examined in duodenal and jejunal enterocytes of Japanese quail reared under normal conditions or subjected to simulated microgravity from day 2 after hatching to 56 days of age.

\section{Materials and Methods}

The experiment was carried out at the Institute of Animal Biochemistry and Genetics of SAS in Ivanka pri Dunaji. One hundred-eight female, newly hatched Japanese quail chicks (Laying Line 01, Ivanka pri Dunaji) were used in the study. On the second day after hatching the chicks of the experimental group were placed in individual slings suspended by a flexible metal device such that their legs could not touch the floor. However, chicks could move about freely by moving their wings. The size of the slings was enlarged from $4 \times 3 \mathrm{~cm} ; 5 \times 4 \mathrm{~cm} ; 6 \times 5 \mathrm{~cm} ; 7 \times 6 \mathrm{~cm}$ and $8 \times 7 \mathrm{~cm}$ to accommodate the growth of the quail. This method was developed and used by the Institute of Animal Biochemistry and Genetics of SAS in Ivanka pri Dunaji (Juráni et al. 1983). At the same time quail chicks of control group were placed in the rearing box $0.6 \times 0.6 \times 0.3 \mathrm{~m}$. The birds of the experimental and control group were kept in the respective conditions until day 63 of age in a windowless poultry room with controlled ventilation and electrical heating by infrared lamps. The temperature was adjusted from $35-36{ }^{\circ} \mathrm{C}$ for the first few days after hatching, to $20{ }^{\circ} \mathrm{C}$ in 4 weeks and remained at this level until the end of the experiment. A commercial starter mash HYD-13 and water were available ad libitum. However, their food consumption was not measured. The diet was granular and contained $260 \mathrm{~g} / \mathrm{kg}$ protein and $11.5 \mathrm{MJ}$ metabolisable energy $/ \mathrm{kg}$. The lighting in the rearing room was left on continuously. Immediately after killing, on day 5, 7, 14, 21, 28, 35, 42, 56 and 63 of age small excisions of the proximal duodenum and middle part of the jejunum were immediately removed, the lumen rinsed in distilled water and frozen in liquid nitrogen. The frozen tissue was cut $(7 \mu \mathrm{m})$ in a cryostat at $-25^{\circ} \mathrm{C}$ and the tissue sections were transferred to supporting glass slides and air-dried. Each group consisted of 6 birds. Demonstration of alkaline phosphatase activity was performed by using a modified simultaneous azocoupling method (Lojda et al. 1979). The incubation medium contained naphtol AS - BI phosphate (Sigma, Germany), Fast blue BB (Aldrich, Germany), and veronal acetate buffer ( $\mathrm{pH}$ 9.2). The samples were incubated at $37^{\circ} \mathrm{C}$ for $10 \mathrm{~min}$, using substrate concentration of $2.0 \mathrm{mmol} / 1$ and $\mathrm{pH} 8.9$. Enzyme activity was cytophotometrically analyzed with a Vickers M85a microdensitometer. The measurements were performed using $\times 40$ objective, an effective scanning area of $28.3 \mu \mathrm{m}^{2}$ and a scanning spot of $0.5 \mu \mathrm{m}$. The integrated absorbance was measured at a wavelength of $480 \mathrm{~nm}$. The mask was set over at least 30 brush border areas along the villus length in five sections of the duodenum and the jejunum. The AP activity was calculated as the absorbance values recorded by the instrument $/ \mathrm{min} / \mu \mathrm{m}^{3}$ brush border and their mean values were referred to one animal. Statistical analyses were carried out using the statistical package Statistica 6.1 (Stat Soft CR, Prague, Czech Republic). The effect of age, hypodynamy and their interaction on AP activity were analyzed by two-way ANOVA with post-hoc Fisher's LSD test. Data were expressed as mean \pm SE and the statistical significance was accepted at the $P<0.05$ level. 


\section{Results}

The brush-border bound alkaline phosphatase (AP) activity in the duodenum and jejunum of control and hypodynamy quails is shown in Table 1 and 2. As compared with control quails exposed to normal gravity, the experimental animals displayed a significantly increased enzyme activity along the intestinal villus till days 42 and 35 in the duodenum and jejunum, respectively. The differences of AP activity between these groups represent about $21 \%$ in the duodenum and $23 \%$ in the jejunum on day 5 . Such tendency has also been confirmed in the consecutive age categories and the increase of AP activity of hypodynamy quails consistently exceeded the values of controls on day 42 in duodenum (about 18\%) and on day 35 in the jejunum (about 19\%). In contrast, in older age categories no significant enzymatic differences between these groups have been found. It corresponded with the findings that the activity of AP in the control birds did not change substantially during the whole studied periods whereas the AP activity in the hypodynamy groups significantly decreased in the duodenum on days 56 and 63 as well as in the jejunum on days 42,56 and 63. Moreover, two-way ANOVA test revealed a significant effect of the hypodynamy treatment on AP activity in both structures of the small intestine $(\mathrm{F}=75.8, P<0.0001$ in the duodenum and $\mathrm{F}=81.7, P<0.0001$ in the jejunum). In this way a significant interaction between treatment $\times$ age $(\mathrm{F}=2.1, P<0.05$ in the duodenum and $\mathrm{F}=2.4, P<0.05$ in the jejunum) on enzyme activity could be observed.

Table 1. Duodenal activity of alkaline phosphatase (AP) in control and in experimental Japanese quails subjected to long-term simulated hypodynamy

\begin{tabular}{|c|c|c|}
\hline \multirow{2}{*}{$\begin{array}{c}\text { Age } \\
\text { (days) }\end{array}$} & AP & Activity \\
\cline { 2 - 3 } & Control & Hypodynamy \\
\hline 5 & $6.03 \pm 0.22^{\mathrm{a}}$ & $7.30 \pm 0.12^{\mathrm{a}^{* * *}}$ \\
\hline 7 & $6.05 \pm 0.18^{\mathrm{a}}$ & $7.25 \pm 0.20^{\mathrm{a}^{* * *}}$ \\
\hline 14 & $6.31 \pm 0.25^{\mathrm{a}}$ & $7.17 \pm 0.30^{\mathrm{a}^{*}}$ \\
\hline 21 & $5.73 \pm 0.08^{\mathrm{a}}$ & $7.07 \pm 0.21^{\mathrm{a}^{* * *}}$ \\
\hline 28 & $5.68 \pm 0.36^{\mathrm{a}}$ & $7.27 \pm 0.35^{\mathrm{a}^{* * *}}$ \\
\hline 35 & $5.98 \pm 0.08^{\mathrm{a}}$ & $7.16 \pm 0.35^{\mathrm{a}}$ \\
\hline 42 & $6.05 \pm 0.18^{\mathrm{a}}$ & $6.35 \pm 0.29^{\mathrm{b}}$ \\
\hline 56 & $6.30 \pm 0.11^{\mathrm{a}}$ & $6.45 \pm 0.25^{\mathrm{b}}$ \\
\hline 63 & $6.11 \pm 0.28^{\mathrm{a}}$ & \\
\hline
\end{tabular}

Values are means \pm S.E.M. ( $=6$ animals/groups). AP activity is given as integrated absorbance in duodenal enterocytes at the wavelength of $480 \mathrm{~nm}$. Parameters within control and hypodynamy columns not sharing the common superscript differ from each other by $P<0.05$. Values with asterisk denote significant differences among control and hypodynamy groups of the same age: $* P<0.05, * * P<0.01, * * * P<0.001$ by post-hoc Fisher's LSD multiple comparison test after ANOVA.

\section{Discussion}

The distinct functional changes in small intestine observed in the present experiment are in agreement with our previous study in which significantly enhanced AP activity in duodenal and jejunal enterocytes was demonstrated in chicks exposed to short-term weightlessness (Lenhardt at al. 2001). Furthermore, our results revealed a transient character of these changes, i.e. the previously acquired functional differences between control and experimental quails gradually disappeared in later periods of hypodynamy. In agreement with this, from day 56 and day 42 the specific AP activity of duodenal and jejunal enterocytes did not significantly differ between both groups. The exact mechanism inducing these opposite functional changes during similar feeding conditions throughout hypodynamy has not been fully elucidated. It has been well established that a crucial requirement for normal growth 
Table 2. Jejunal activity of alkaline phosphatase (AP) in control and in experimental Japanese quails subjected to long-term simulated hypodynamy

\begin{tabular}{|c|c|c|}
\hline \multirow{2}{*}{$\begin{array}{c}\text { Age } \\
\text { (days) }\end{array}$} & AP & Activity \\
\cline { 2 - 3 } & Control & Hypodynamy \\
\hline 5 & $5.70 \pm 0.20^{\mathrm{a}}$ & $7.02 \pm 0.24^{\mathrm{a}^{* * *}}$ \\
\hline 7 & $5.73 \pm 0.21^{\mathrm{a}}$ & $7.05 \pm 0.23^{\mathrm{a} * * *}$ \\
\hline 14 & $5.91 \pm 0.14^{\mathrm{a}}$ & $6.95 \pm 0.20^{\mathrm{a}^{* * *}}$ \\
\hline 21 & $5.45 \pm 0.29^{\mathrm{a}}$ & $6.72 \pm 0.30^{\mathrm{a}^{* * *}}$ \\
\hline 28 & $5.68 \pm 0.17^{\mathrm{a}}$ & $6.78 \pm 0.17^{\mathrm{a}}$ \\
\hline 35 & $5.65 \pm 0.22^{\mathrm{a}}$ & $6.70 \pm 0.22^{\mathrm{a}^{* * * *}}$ \\
\hline 42 & $5.97 \pm 0.15^{\mathrm{a}}$ & $6.30 \pm 0.25^{\mathrm{b}}$ \\
\hline 56 & $5.93 \pm 0.10^{\mathrm{a}}$ & $6.00 \pm 0.14^{\mathrm{b}}$ \\
\hline 63 & $5.85 \pm 0.11^{\mathrm{a}}$ & \\
\hline
\end{tabular}

Values are means \pm S.E.M. ( $\mathrm{n}=6$ animals/groups). AP activity is given as integrated absorbance in jejunal enterocytes at the wavelength of $480 \mathrm{~nm}$. Parameters within control and hypodynamy columns not sharing the common superscript differ from each other by $P<0.05$. Values with asterisk denote significant differences among control and hypodynamy groups of the same age: $* * * P<0.001$ by post-hoc Fisher's LSD multiple comparison test after ANOVA.

and development of the small intestine is the presence and amount of food in the alimentary tract. Fasting immediately after hatch does depress subsequent growth of the intestine and development of the intestinal mucosa (Baranyiová 1972; Baranyiová and Holman 1976; Geyra et al. 2001). Similarly, early nutrient restriction of broiler chickens results in a reduced weight of the gastrointestinal organs and a decreased jejunum cell number (Palo et al. 1995). Moreover, in newly-hatched chickens significant enzymatic changes occur in the small intestine and these changes are considered as functional adaptation of the small intestine to the qualitative nutritional changes such as is gradual replacement of yolk sac rich in lipids with solid carbohydrate-rich food (Noy and Sklan 1999, 2001; Sklan 2003). Such a relation seems to be in agreement with experiments where in broiler chicks the duodenal and jejunal AP activity reaches the highest values at the time of hatching and its activity subsequently decreased on days 2-4 of age (Uni et al. 1998).

Although the persistent decrease in food or energy intake has been observed in Japanese quails submitted to some experimental hypodynamy as in present experiment (Škrobánek et al. 2004) some differences regarding hormonal and metabolic status as well as the intestinal function between young and older animals do exist. It was found that in posthatch quails hypodynamy results in adrenal hypertrophy (Cigánková et al. 2005) and substantial elevation of plasma corticosterone (Juráni et al. 1983) whereas with long lasting hypodynamy a gradual adaptation to the stress was observed, i.e. corticosterone concentration decreased progressively to the normal values on day 60. Similarly, an opposite effect of early insufficient nutrition has been observed on overall feed efficiency. In younger chicks the hypodynamy elicited decreased utilization of the ingested nutrients while in older animals it resulted in improved feed utilization (Škrobánek et al. 2004). Moreover, as compared to the controls, the hypodynamy quails, as stated in the present study, exhibited a significantly different AP activity even when they were exposed to entirely similar nutrition after hatching. In 5-35-day-old chicks AP activity significantly increased whereas its activity in duodenum and jejunum returned to normal values at later periods of experiment. In addition, the present results, together with previous work (Lamošová et al. 2003), have shown that AP activity in control quails exposed to normal gravity displayed only minimal variations throughout all the periods followed. Considering the finding that enzymatic changes were proportional to the extent of previous stressful situations, it is possible that their early adverse influence was sufficient to induce maximal elevation of 
enzyme values but this was not the case in long-term hypodynamy. From this point of view, the decreased AP activity in older quails is probably not a consequence of actual nutritional variations, but could rather be a part of a more general effect of simulated microgravity characterized by hormonal and metabolic alterations (Juráni et al. 1983; Antalíková et al. 2001; Škrobánek and Hrančová 2003).

The present results extend our knowledge about brush-border-bound AP activity in Japanese quails and allow a better understanding of the intestinal mechanisms that may predetermine the capability of quail chicks to adapt to long-term weightlessness. Our results indicate that the simulated hypodynamy significantly affects the development of the intestinal epithelium and particularly the changes in small intestine function from day 35 after hatching might be considered as critical for improvement of earlier metabolic and somatic disturbances. However, we suppose that different activities of AP in the small intestine were not only a direct result of hypodynamy but also may have resulted from insufficient intake of food in Japanese quail reared under simulated microgravity conditions. The question of irreversibility of these changes and their importance for further periods of life, however, remains open and requires further experiments.

\section{Vplyv dlhodobej simulovanej hypodynamie na enzymatickú aktivitu tenkého čreva u kurčiat japonskej prepelice}

V práci bol sledovaný funkčný vývoj tenkého čreva u kurčiat japonskej prepelice vystavenej simulovanej mikrogravitácii (hypodynamii) po vyliahnutí, od 2 do 63 dňa veku. Na 5., 7., 14., 21., 28., 35., 42., 56. a 63. deň bola stanovená aktivita alkalickej fosfatázy (AF) $\mathrm{v}$ mikrovilóznej zóne enterocytov duodena a jejuna u experimentálnych ako aj u kontrolných kurčiat chovaných za štandardných podmienok počas celého experimentu. V porovnaní s kontrolnými kurčatami, u experimentálnych zvierat bola zaznamenaná signifikantne zvýšená enzymatická aktivita AF do 42. dňa v duodene a do 35 . dňa v jejune $(P<0,001)$. U starších vekových kategórií sme signifikantné rozdiely medzi sledovanými skupinami nepozorovali. Aktivita AF v tenkom čreve kontrolných kurčiat nevykazovala podstatné zmeny v sledovaných periódach. Avšak u starších hypodynamických kurčiat aktivita AF sa signifikantne znížila na 56. a 63. deň v duodene a na 42., 56. a 63. deň v jejune. Tieto výsledky naznačujú, že a) zvýšenie intestinálnej funkcie v ranných periódach života pravdepodobne odzrkadl'ujú vyššiu citlivost' tenkého čreva na simulovanú mikrogravitáciu, b) zníženie aktivity AF u starších zvierat na úroveň ich kontrol môže byt' súčast'ou intestinálnych mechanizmov zúčastňujúcich sa adaptácii na dlhodobú hypodynamiu u japonských prepelíc, c) zmeny v aktivite AF v tenkom čreve mohli vzniknút' nielen vplyvom hypodynamie, ale aj v dôsledku zníženého príjmu potravy.

\section{Acknowledgement}

This work was supported by the Grant Agency for Science of Slovak Republic VEGA 1/ 3495/ 06 and $2 / 5141 / 25$.

\section{References}

ANTALÍKOVÁ J, BARANOVSKÁ M, MRAVCOVÁ I, SABO V, ŠKROBÁNEK P 2001: Different influence of hypodynamy on calcium and phosphorus levels in bones of male and female Japanese quails. Physiol Res 50: $197-204$

BARANYIOVÁ E 1972: Influence of deutectomy, food intake and fasting on the digestive tract dimensions in chickens after hatching. Acta Vet Brno 41: 373-384

BARANYIOVÁ E, HOLMAN J 1976: Morphological changes in the intestinal wall in fed and fasteded chickens in the first week after hatching. Acta Vet Brno 45: 151-158

CIGÁNKOVÁ V, ZIBRÍN M, BOĎA K, HOLOVSKÁ K 2005: Effect of long-term experimental hypodynamy on the adrenal glands of Japanese quails: An ultrastructural study. Bull Vet Inst Pulawy 49: 449-453 
GEYRA A, UNI Z, SKLAN D 2001: The effeet of fasting at different ages on growth and tissue dynamics in the small intestine of the young chicks. Br J Nutr 86: 53-61

JURÁNI M, VÝBOH P, LAMOŠOVÁ D, BAROŠKOVÁ Z, SOMOGYIOVÁ E, BOĎA K, GAŽO M 1983: The effect of a 90-day hypodynamy on the neurohumoral system, egg laying and metabolism of protein in Japanese quail. Physiologist 26: 145-148

JURÁNI M, BOD̃A K, KOŠŤÁL L', SOMOGYIOVÁ E, LAMOŠOVÁ D, VÝBOH P, AMBRUŠ B, BAUMGARTNER J 1988: Selection of Japanese quail line resistant to hypodynamy. Physiologist 31: 140-141

LAMOŠOVÁ D, MAČAJOVÁ M, ZEMAN M, MOZEŠ S, JEŽOVÁ D 2003: Effect of in ovo leptin administration on the development of Japanese quail. Physiol Res 52: 201-209

LENHARDT L, CIGÁNKOVÁ V, ZIBRÍN M, KOČIŠOVÁ J, TOMKOVÁ I, SABO V, BOĎA K, DADASHEVA OA, GURIEVA TS, MOZEŠ Š 2001: Functional development of small intestine of Japanese quail hatched on MIR orbital station. Acta Vet Brno 70:127-131

LOJDA Z, GROSSRAU R, SCHIBLER TH 1979: Enzyme Histochemistry. Springer- Verlag, Berlin, pp. 59-70

NOY Y, SKLAN D 2001: Yolk and exogenous feed utilization in the posthatch chick. Poult Sci 80: 1490-1495

NOY Y, SKLAN D 1999: Energy utilization in newly hatched chicks Poult Sci 78: 1750-1756

RAJMAN M, JURÁNI M, LAMOŠOVÁ D, MAČAJOVÁ M, SEDLÁČKOVÁ M, KOŠŤAL L', JEŽOVÁ D, VÝBOH P 2006: The effects of feed restriction on plasma biochemistry in growing meat type chickens (Gallus gallus). Comp Biochem Physiol A Mol Integr Physiol 145: 363-371

SHAPIRO F, NIR I, HELLER D 1998: Stunting syndrome in broilers: Effect of stunting syndrome inoculum obtained from stunting syndrome affected broilers, on broilers, leghorns and turkey poults. Poult Sci 77: 230-236

SKLAN D 2003: Fat and carbohydrate use in posthatch chicks. Poult Sci 82:117-122

ŠKROBÁNEK P, HRANČOVÁ M 2003: Adaptability of Japanese quail chicks to conditions of simulated weightlessness. Acta Vet Brno 72: 347-51

ŠKROBÁNEK P, HRBATÁ M, BARANOVSKÁ M, JURÁNI M 2004: Growth of Japanese quail chicks in simulated weightlessness. Acta Vet Brno 73: 157-164

ŠKROBÁNEK P, BARANOVSKÁ M, JURÁNI M, ŠÁRNIKOVÁ B 2005: Influence of simulated microgravity on leg bone development in Japanese quail chicks. Acta Vet Brno 74: 475-481

UNI Z, NOY Y, SKLAN D 1995: Posthatch changes in morphology and function of the small intestines in heavy and light-strain chicks. Poult Sci 74: 1622-1629

UNI Z, GANOT S, SKLAN D 1998: Posthatch development of mucosal function in the broiler small intestine. Poult Sci 77: 75-82

UNI Z, NOY Y, SKLAN D 1999: Posthatch development of small intestinal function in the poultry. Poult Sci 78: 215-222

VAN DER ZIEL CE, VISSER GH 2001: The effect of food restriction on morphological and metabolic development in two lines of growing Japanese quail chicks. Physiol Biochem Zool 74: 52-65

WEISER MM 1973: Intestinal epithelial cell surface membrane glycoprotein synthesis. I. An indicator of cellular differentiation. J Biol Chem 248: 2536-2541 